\title{
COMMUNICATIVE INTENTION AS A LINGUISTIC PHENOMENON: CATEGORICAL STATUS AND VERBALIZATION
}

\begin{abstract}
Summary. The article deals with the communicative intention as an important anthropo-oriented linguistic phenomenon that has a direct relation to the person, his mind, and intellect and is represented by a number of grammatical units that clearly expose the speaker as the bearer of intention in text communication. The inter-layered categorical status of the communicative intention, represented by units of different language levels, is defined in the process of analysis, specifically, discursive, syntactic, morphological, and lexical markers of intentional verbalization of intention are systematized. Undoubtedly, the intention is an important component of a person's mental state, but it is explicated with the help of grammatical means of the language and becomes understandable to other participants of communications.
\end{abstract}

Communicative intention is a linguistic category in which the content (the speaker's intentional needs: to inform, to tell, to ask, to encourage, to wish, to react emotionally, to appreciate, to thank, to apologize, to sympathize, to praise, etc.) and a plan for language representation plan are clearly explicated. This is one of the important anthropo-oriented categories, because it is always correlated with the speaker - the bearer of various intentions, who determines the intentional scope of communication, selects a system of language means (generally accepted or figuratively-rhetorical, direct or indirect constructions) for their implementation, forms a continuum of interaction, determines the development of tolerant or zero tolerant communication. The dominant means of verbalizing the communicative intention as an inter-level category are discourse-genre statements, realized in two genre registers - dialogic and monologic, and, of course, syntactic constructions in which lexical and morphological units find their functional perfection.

In this article a number of linguistic methods (descriptive, structural, contextual-interpretive, method of distributive analysis) are used to highlight the categorical status of communicative intention, to systematize multilevel means of its verbalization in text communication, and to interpret this anthropocentric concept as a separate linguistic phenomenon.

Key words: communicative intention, speaker, category, inter-layered status, verbalization, expression, communication.

Introduction. The anthropocentric direction of modern linguistics emphasizes the dynamic development of linguistic studies that are aimed at elevating a human being in the process of communication and are related to the conceptualization and lingualization of the world, to the global intentions of the speaker and to material manifestations, serving as means for verbalization of the intentional space of the linguistic persona. Within these issues, we consider it important to find solutions to the questions related to the category of communicative intention, the difficulty of study of which is stipulated by the fact that it harmoniously combines such crucial concepts of the process of communication as the world (objective reality, setting), utterances (means of realizing of the speech intention) and the author (the speaker as the bearer of various intentional states). The systematic study of communicative intention as a separate linguistic phenomenon clearly reflects the change of the priorities in the contemporary linguistics - from structuralism to anthropocentrism, to the linguistics of the speaker and grammar of the utterance.

Analysis of recent research and publications on this topic. The problems linked with the category of intention comprise the list of those contradictory issues of linguistics that do not lose their relevance, on the contrary, they acquire new perspectives of studying. The term "communicative intention" is the basic concept of some linguistic theories (the speech act theory, the theory of speech activity and the theory of speech influence) in the framework of which it is correlated with illocution, subjective-modal meaning, motivational sphere of the linguistic persona, strategies and tactics of the process of communication (G. Grice, J. Austin, P. Strawson, J. Searle, O. Issers, O. Kamenskaya, V. Krasnykh, A. Leontiev, etc.) and it is also considered alongside such grammatical concepts as modality, objectivity, communicative attitude, actual division (I. Anders, I. Vykhovanets, A. Zahnitko, M. Mirchenko, etc.).

Intention is defined in linguistic studies as a speech intent or will of the speaker [1, p. 409]; conscious or intuitive intent of the addressee, which determines the internal program of speaking and the way it is implemented [2, p. 116]; as a kind of desire: the speaker's desire to tell something, to request or ask [6, p. 74]; the intent of the addressee and the content of the statement [9, p. 29-30]; communicative attitude and the purpose of the utterance [3, p. 29]; the foundation of the typology of speech genres [2, p. 54]; text-forming factor $[8$, p. 8]. However, the mentioned scientific works do not give a complete and holistic view of the categorical status of communicative intention, the system of means of its verbal and non-verbal implementation.

The purpose of the article is to justify categorical status of communicative intention, to investigate lexical and grammatical discourse markers of its implementation in the Ukrainian language, to identify means of verbalization of the speaker's substance as the author of intention in text communication - in its tolerant or non-tolerant dimension.

Results and discussion. Modern linguistics needs a new definition of the concept of intention, based on its anthropocentric, cognitive, grammatical and discursive parameters. Our interpretation of this concept, first of all, extends the limits of perception of intention, in particular, its understanding not only as a mean- 
ingful or intuitive intent of the speaker and the desire of the subject of communication but primarily as the properties of linguistic units. Secondly, it allows us to interpret communicative intention as a universal linguistic category, which has an inter-level character and is represented by statements, sentence equivalents, discursive constructions. Actually, we consider it proper for the linguistic analysis to regard intention as a category, where the plan of content (the speaker's intentional need to inform, to tell, to ask, to encourage, to wish, to react emotionally to something, to appreciate, to thank, to apologize, to sympathize, to praise etc.) and the plan of expressionmeans and ways of verbalization of the intentional space of the linguistic persona are distinctly explicated.

In our opinion, the communicative intention has a polystatus linguistic character, since its content covers not only the world of human existence, but also the world of verbalization of speech. First of all, this is a conceptual inter-level category, determined by philosophical, psychological and cognitive parameters and represented by units at different levels of language. The dominant tools of the verbalization of the category of communicative intention are syntactic constructions, in which lexical and morphological units find their functional completeness.

At the same time, it is a communicative category that determines the process of human communication and, in general, the intentional structure of the utterance, which accumulates information about the psychological space of the linguistic personality, reveals the speaker's position, his / her needs and goal set.

Finally, it is an explicit cognitive category that correlates with the phenomena of the real world on the preverbal level and serves as a medium connecting language and thinking, language and consciousness. Categorization of mental or psychic resources of ourmind and, consequently, of intentions as the basic knowledge of the world of the linguistic persona can occur with the help of concepts that represent knowledge and experience of the man. Cognitive manifestations of intentions are directly dependent on a number of psychic phenomena, the conceptual system of the worldview, the perception of linguistic and cultural community to which the linguistic persona belongs, the communicative competence of the participants of communication, the social role of the addressee, the type of interaction, and on language units belonging to different levels that structure and store knowledge and experience of the subject of communication through activities of the speaker.

Such a broad interpretation of the communicative intention provides it with an important place in the discourse of social and human sciences, and not only in linguistics. For example, even in studies on philosophy, provisions were made that intentionality initiates consciousness, and the linguistic sign is used to express the intentional state and content (F. Brentano, E. Husserl, V. Ladov). In the works of domestic and foreign scholars, an important role of intention in the life of each individual is established, since this is the basic linguistic substance that determines and organizes the multi-vector process of human communication.

The category of communicative intention is one of the important modular, anthropocentric categories, because it is always correlated with a speaker, a carrier of various intentions, who determines the intentional expanses of communication, chooses a system of linguistic means (common or figurative-rhetorical, direct or indirect constructions) for their implementation, forms the addressant-addressee continuum of interaction, determines the development of tolerant or non-tolerant communication.
Anthropo-orientation of intention as a linguistic phenomenon is obvious since the intention is first of all the prerogative of the speaker, the main participant in the process of communication. Moreover, the speaker is the conveyor of intentions and determines the intentional perspectives of communication. At the same time, verbalization of speech intentions is directly dependent on the inner world of the subject of communication, his objective and intention, which become decisive for the utterance or the beginning of the interaction.

Explication of the speaker - the author of the intention is achieved by means of a number of grammatical markers in Ukrainian: 1) the personal pronoun I, which emphasizes the individuality, identity and self awareness of the linguistic persona, cf.: I came here to the world and met the sun, bathed my feet in the morning dew (N. Tsaruk); 2) the personal pronoun We in the semantic space of which we observe the coding of not only of the agent but also of other participants in the process of communication: And during the enjoyable holidays, and on weekdays we think, great-grandsons, about you (V. Symonenko); 3) case forms of pronouns (me, etc.), e.g.: do not disregard me, do not neglect, but hug me and dove (B. Melnychuk). How can I feel sorrow without you? How can I weep my heartsore without you? (N. Tsaruk); 4) first person singular and plural of possessive pronouns (mine, your) that intensify the egocentricity of the speaker's «I», for example: And what is the saddest: my torment is useless, 'cause treason is a dark and dirty thing (L. Kostenko); In general, I'm glad that my poems caused a critical talk (Lesia Ukrainka). Possessive pronouns partly point to the subject of intentions, expressing the importance of something belonging to a person, $\mathrm{cf}$ :: O my unfree liberated people, You go to the crucifixion $<. .>$ And I'm with you Through the sharp light, yours, and mine-Both crosses carry (T. Severniuk); 5 ) the first person singular or plural in the present or future tenses in the indicative mood: I bless those footprints, I bless the roads that brought me here - to the star-studded palaces of art (L. Kostenko); Ukraine! O, mother! To you we'll swear an oath (M. Voronyi); 6) the first person plural of the imperative mood - Vasyliu, let's go to the forest to pick berries! (B. Hrinchenko); 7) subjective-modal words and phrases (in my opinion, to my mind, it seems to me, perhaps, probably, obviously, etc.), which represent the author's position, the subjective attitude of the speaker to the reported or seen, convey the author's opinion on a certain situation, determine the axiological parameters of oral-colloquial or textual communication. For example: - In my opinion, it is long overdue to create a management of the Dnieper basin (I. Tsiupa); - Perhaps there is no more truth in the world. Maybe, it has fled overseas (E. Hrebinka). $\mathrm{N}$. Formanovska correctly observes that intention is a «certain mental state of a person and is close to such phenomena as emotion, desire, evaluation, attitude to reality, to the content of the message to the addressee» $[9$, p. 29]. Undoubtedly, the intention is an important component of a person's mental state, but it is explicated with the help of grammatical means of the language and becomes understandable to other participants of communications.

The communicative intention is directly connected with logical categories and philosophical universals; therefore, it may be regarded as a conceptual category in the content plan and as a linguistic one in the way of explication. In fact, its categorical status follows from the "bilateral understanding of the linguistic sign and the bilateral essence of language as a phenomenon, that includes a plan for language content and a plan of expression" [4, p. 29]. As is known, 
to distinguish a certain category, it is necessary to have a number of forms possessing some common meaning so that there is an opposition within this union and that the opposing values have a formal expression. As for the communicative intention, syntactic constructions, beginning from the syntaxeme to the complex syntactic unit, units of the lexical and morphological levels can express an intentional meaning and convey the content relevant to a particular speech situation. Thus, declarative, interrogative, imperative, conditional statements are contrasted depending on the tasks the speaker who joins the process of communication has, but they are united by the intention - the universal linguistic notion that is formally expressed, reveals extensive intentional horizons of communicants and is semantically informative.

Undeniably, any category is a combination of constructs (linguistic units) based on a certain concept (feature). Actually, the communicative intention is this unifying parameter. This parameter is mandatory, because it forms the intentional structure of any utterance, for, as M. Bakhtin points out, "we realize, understand, feel the speaker's intention or the verbal will of the speaker in every utterance, from a single-word everyday remark to large complex works of science or literature" [1, p. 409]; it is subjective, since intention is always related to the speaker, the creator of the particular utterance, the subject of intention; it is dynamic, because it reflects the actual speech act or textual communication; it is constant regarding the system of its means of verbalization (the language unit either realizes this category or not). At the same time, the communicative intention is an inter-layered linguistic category realised by such components as syntagmas, communicators, and utterances. Lexical and morphological means reveal their communicative-intentional potential in the utterances, which we consider to be the most relevant means of verbalization of intention.

According to our observations, the inter-level status of the category of the communicative intention is realized by linguistic units of different levels:

a) lexical because lexemes form utterances expressing a certain intention (emotional, evaluative), e.g.:-My merciful God, how happy I am! (M. Vinhranovskyi); - I am touched by the fact that you've read my father's books (I. Tsiupa). Nouns and adjectives express axiological intention, the content range of which is represented by two ambivalent intentions: the intention of appraisal labeled with the concepts "good", "well": -What a clever girl! (G. Tarasiuk);What a beauty! Well, dolly girl! (A. Dovzhenko ); and evaluative intention, expressing the meaning "bad", "evil": - Well, you are the fool (V. Shevchuk); - Go, scoundrel. Don't drive me into frenzy (M. Stelmakh);

b) morphological because words belonging to different parts of speech have different valency and potentiality to verbalize the intention. For example, verbs will definitely convey this or that intention, refer to performativity and verbalize the intentions of promise, request, gratitude, etc.: - I swear by the sky adorned with the constellation of the zodiac (P. Zahrebelnyi); - I beg you to come to me (V. Vynnychenko); - Oh, thank you for your care, your grace! (V. Vynnychenko); interrogative pronouns and adverbs may express the intention of request: - Who is wandering there? (V. Pidmohilnyi); - Whom has she bought such a good and beautiful pysanka? (G. Kvitka-Osnovyianenko); -And where are you from? Whence do you come? (Ivan Bahrianyi); exclamations realize the intention of command (-Enough! Confess, who are you?
(V. Vynnychenko); - Here you must sit where your new name is written! Off you go! (I. Franko);

c) syntactic because explication of a certain intention, its interpretation and recognition occurs at the level of utterances and sentence equivalents that express intention of: declaration, the content range of which is focused on the representation of a certain intellectual experience of the speaker, his knowledge and skills ( I live in a country of schedrivka and vesnianka, where the evening dawn comes to the porch and listens to the song of childhood (M. Synhayivskyi); interrogation that transmits a multi-vector cognitive process aimed at elucidating certain information or clarifying it (-Mum! What girl came to us yesterday to spot the fire? (I. NechuiLevytskyi); command, which reflects the will of the speaker, different in intensity and syntactic organization (- Immediately sit down here at my table and write a petition (I. Tsiupa); - Let's run to the Danube! (S. Sklyarenko); condition, which represents the desire of the communicator to perform the potentially desired action (- If only my beloved strip of land! If only the gray straw of the great-grandfather's roofs! (E. Malaniuk);

d) discourse-genre as a dominant, vertex level, associated primarily with the functional-style and genre differentiation of speech, with the dominant intentions of various discourses. In this case, the intention is verbalized through text structures realized in two communicative registers - dialog, reflecting the event that arises as a result of interaction between the two communicators: - Are you already going, son? - I go, mother (V. Stefanyk), and monolog transmitting the one-sided, individual communicative line of the addressee and represents a broad content range: contemplation about individual life realities or people, evaluation of reality, for example: For your only braids, for only your voice you are worthy of love... How can such words be born in the depths of the human soul, like the stars on the eyelashes of the night? And is it not a miracle that everyone finds love in their own way and loves everyone in their own way? (M. Stelmakh). Speech acts built on the principles of courtesy, sincerity, trust, and compromise represent tolerant communication: the participants hold a straightforward dialogue, have balanced relationships, mutual role, and behavioral expectations, retain a benevolent tone of communication therefore successfully verbalize their intentions: - What is it, baby? - This is a silver halfkarbovanets (M. Stelmakh). If communication does not encourage manifestation of positive qualities of subjects of speech, then the communicative event is regulated by strategies of confrontation, conflict, which suggests, first of all, incompatibility of views of communicators, unrealized intentions, and non-tolerant communication:-Are you looking for someone? - And what has that to do with you? (O. Honchar).

The system of means belonging to different levels of verbalization of the intentional scope of human communication, the categorical status and versatility of the phenomenon of intention outline its typological manifestation (cognitive-mental, communicative-modal, subjective-modal, discursive and genre, metacommunicative intentions) [10, p. 167], differentiation of which is based on the factors that take into account: 1) the standard spectrum of the speaker's intentional needs (to approve or reject information, to ask, to encourage to perform an action, to express desire / wish / assessment, to declare respect, to thank, etc.); 2) correlation of ways the intention is verbalized in the statement/discourse (genre); 3 ) intention relation to the paradigm of the basic speech needs or to the discourse of phatic communication; 4) the intentional dominant 
of a discursive utterance; 5) lexico-grammatical means of intention explication (modal-intentional and discursive expressions, sentence equivalents, forms of verbs, nouns, adjectives, etc.). Actually, the designation of the role of each of these factors in the process of verbalization of communicative intention in various Ukrainian discursive-genre manifestations constitutes the subject of our further scientific research.

Conclusions. Thus, communicative intention is a linguistic category in which the content (the speaker's intentional needs: to inform, to tell, to ask, to encourage, to wish, to react emotionally, to appreciate, to thank, to apologize, to sympathize, to praise, etc.) and a plan for language representation plan are clearly explicated. This is one of the important anthropo-oriented categories, because it is always correlated with the speaker - the bearer of various intentions, who determines the intentional scope of communication, selects a system of language means (generally accepted or figuratively-rhetorical, direct or indirect constructions) for their implementation, forms a continuum of interaction, determines the development of tolerant or zero tolerant communication. The dominant means of verbalizing the communicative intention as an inter-level category are discourse-genre statements, realized in two genre registers - dialogic and monologic, and, of course, syntactic constructions in which lexical and morphological units find their functional perfection.

A comprehensive analysis of the category of intention indicates a multi-vector direction of modern linguistics, reveals a close relationship between different linguistic levels and categorical values, promotes the development of communicative grammar, anthropo-oriented and completely relevant for linguistics of the 21 st century.

\section{References:}

1. Бахтін М. Висловлювання як одиниця мовленнєвого спілкування. Антологія світової літературно-критичної думки XX ст. / за ред. М. Зубрицької. Львів : Літопис, 2001. С. 406-415.

2. Бацевич Ф.С. Лінгвістична генологія: проблеми і перспективи. Львів, 2005. $264 \mathrm{c}$.

3. Бондарко А.В. К проблеме интенциональности в грамматике. Вопросы языкознания. 1994. № 2. С. 29-42.

4. Вихованець І., Городенська К. Теоретична морфологія української мови / за ред. І. Вихованця. Київ : «Пульсари», 2004. 400 с.

5. Остин Дж. Слово как действие. Новое в зарубежной лингвистике. Москва : Прогресс, 1986. Вып. 17. С. 22-129.

6. Почепцов О.Г. Основы прагматического описания предложения. Киев : Высшая школа, 1986. 116 с.

7. Серл Дж.Р. Классификация иллокутивных актов. Новое в зарубежной лингвистике. Москва : Прогресс, 1986. Вып. 17. С. 170-194.

8. Сусов И.П. Уровни языковой системы и лингвистическая семантика. Синтаксическая семантика и прагматика. Калинин, 1982. C. $3-11$
9. Формановская Н.И. Речевое общение: коммуникативно-прагматический подход. Москва : русский язык, 2002. 216 с.

10. Шабат-Савка С.Т. Типология комунікативних інтенцій у лінгвістиці: українськомовний дискурс. Віртус : науковий журнал. 2016. № 9. С. 166-170.

Шабат-Савка С. Т. Комунікативна інтенція як лінгвістичний феномен: категорійний статус і вербалізація

Анотація. У статті проаналізовано комунікативну інтенцію як антропозорієнтований лінгвістичний феномен, що своїм змістом охоплює не тільки світ людського буття, наміри комунікантів, їхній інтелект та свідомість, а й світ мовної вербалізації. На багатому фактичному матеріалі обгрунтовано міжрівневий категорійний статус комунікативної інтенції, систематизовано синтаксичні, морфологічні та лексичні маркери інтенційної вербалізації, окреслено особливості експлікації дискурсивно-жанрових інтенцій, детермінованих стильовою диференціацією мовлення, атмосферою перебігу інтеракції.

Ураховуючи наукові студії зарубіжних та вітчизняних лінгвістів, з'ясовано, що комунікативна інтенція - лінгвістична категорія, у якій виразно експлікується план змісту (інтенційні потреби мовця: поінформувати, оповісти, запитати, спонукати, побажати, емоційно відреагувати на щось, оцінити, подякувати, вибачитися, поспівчувати, похвалити тощо) і план мовної репрезентації. Це одна 3 антропозорієнтованих категорій, тому що завжди співвіднесена 3 мовцем - носієм різноманітних інтенцій, який визначає інтенційні обшири спілкування, добирає систему мовних засобів (загальноприйнятих чи фігурально-риторичних, прямих чи непрямих конструкцій) для їхньої реалізації, формує адресантно-адресатний континуум взаємодії, детермінує розвиток толерантної чи атолерантної комунікації. Домінантними засобами вербалізації комунікативної інтенції як міжрівневої категорії слугують дискурсивно-жанрові висловлення, реалізовані у двох жанрових регістрах - діалогічному та монологічному, i, безперечно, синтаксичні конструкції, у яких функціонально довершуються лексичні та морфологічні одиниці.

У статті використано низку лінгвістичних методів (описовий, структурний, контекстуально-інтерпретаційний, метод дистрибутивного аналізу), аби обгрунтувати категорійний статус комунікативної інтенції та систематизувати багаторівневі засоби ï вербалізації в різних дискурсивно-жанрових формах української мови, щоб репрезентувати це антропоцентричне поняття як окремий лінгвістичний феномен.

Ключові слова: комунікативна інтенція, мовець, категорія, міжрівневий статус, вербалізація, висловлення, дискурс, комунікація. 